\title{
Uninterested and Disengaged: E- literacy and At- Risk College Students
}

\author{
Peggy Blood \\ Savannah State University, Savannah, GA, USA
}

bloodpeg2@bellsouth.net

\begin{abstract}
One of the most critical elements for student success and retention in E-learning classes is being able to be a discipline learner with good study habits. Students must be able to understand the lesson format be able to maneuver software tools for greater comprehension of course content. It would be an ideal situation if all students taking E-learning classes were of similar abilities; motivated to do well and have a clear understanding that time management, independence and self discipline are major key elements in their success in online classes.
\end{abstract}

The quality of on-line education has been on a controversy block since it was introduced into higher education learning; and the debate regarding its validity to learning continues. This paper will address E-literacy skills as being the fundamental set for success with at-risk students.

Several classes were followed over a five year period with various interventions to improve atrisk student learning outcomes and retention in the class. The final year three classes were part of a national study using interventions to improve progress of at-risk students; all classes were taught by the writer. Various intervention strategies were explored to off-set failure rates and class withdrawals; results showed marginal progress.

Poor E-literacy skills, understanding how to maneuver the frameworks, basic reading and comprehension skills have been found as major contributors to this writer's class failure and droprate. Many at-risk students with poor E-literacy skills have a history of poor performance that have followed them throughout their educational journey.

E-literacy skills are defined as comprehending and mastering technology systems used to deliver cyber classes, having the ability to read, write, comprehend, and having developed study skills and habits. At-Risk students for the purpose of this paper is defined as students who are in jeopardy of failing, needs additional support, and who are not meeting or expected to meet the established goals of the institutions' educational programs.

The term online and E-learning will be used interchangeable and will refer to formal and nonformal courses that use an information net work on the internet, an internet (LAN) or external

Material published as part of this publication, either on-line or in print, is copyrighted by the Informing Science Institute. Permission to make digital or paper copy of part or all of these works for personal or classroom use is granted without fee provided that the copies are not made or distributed for profit or commercial advantage AND that copies 1) bear this notice in full and 2) give the full citation on the first page. It is permissible to abstract these works so long as credit is given. To copy in all other cases or to republish or to post on a server or to redistribute to lists requires specific permission and payment of a fee. Contact Publisher@InformingScience.org to request redistribution permission.
(WAN), the terms will be used for partial (hybrid, enhanced) or full course delivery.

Keywords: At-Risk Students, Eliteracy, Retention, E-learning

\section{Introduction}

Online courses are increasingly being examined by institutions and programs; institutions are looking at quality learn- 
ing and retention rates in cyber classrooms; students and faculty are being tracked to determine productivity. Online faculty and student performance are being evaluated; while assessors and expert pedagogy experts struggle to rationalize and reason why some students perform poorly and drop online courses.

At-risk students are venerable to online courses, many are non-traditional students with family obligations, working to support themselves through college, over extended, and in fact many have characteristics of being at-risk students before entering online courses.

This paper will focus on at-risk students enrolled in a historical black institution; using E-learning art classes that are usually designated for first year students. Many of the students enrolled in the classes under study are at-risk. Their profile will be discussed later in another section.

It may not have been originally understood or considered at the time of the culmination of cyber courses that at-risk students would present a major problem with retention and course outcome data. The excitement and vision of revolutionizing education with advanced technology methodology, of which has long been debated as overdue, may have fallen short of the No Child Left Behind aspirations. It has been general knowledge in the academy that at-risk students need more intervention in brick and mortar classrooms; requiring special assistance and motivation. It would seem obvious that the same would be needed for this challenged group in taking E-learning classes. Perhaps with the new found freedom and access; giving students freedom and convenience to go on-line any time within twenty four hours, and revisiting notes and assignments at leisure, may have seemed like a perfect solution for improving outcomes of students with academic deficiencies. However self-paced learning may not always be the solution with students not having "ready -made equipped tools, foundation or the know-how" to be successful online. According to Funk, and Southwest Educational Development Laboratory (SEDL) a number of variables are responsible for students falling in the at-risk category, they may be "related to a student's family or personal background appears to contribute to increasing the risk of failure in school", higher education at-risk learners tend to over extend in extra-curricular activities: campus clubs, social fraternities and sororities, sports, student union socialization and activities, drug s and alcohol addictions, work, financial problems and families. Many at-risk students have positive intentions at the beginning of their classes, but have a history of negative success experience so as they become overwhelmed they become selective as to which classes they may attend and, selective in class assignments. Funk lists other characteristics "consist of limited language proficiency, poverty, race, geographic location, or economic disadvantage." While many at- risk students fall in the categories listed above, many lack skills in time management and study habits (not knowing how to study), they are more likely to take online classes, and tend not to succeed without some type of advisement or intervention. E-learning classes give at-risk students, if not monitored appropriately, the opportunity to procrastinate and hide; not having to face an instructor the next day with an explanation.

Since E-learning requires good to adequate reading and written communication skills, of which many at-risk students have not achieved to a satisfactory level, excuses are voiced easily that the lessons are too communicated or not understood. As mentioned above many at- risk students have a history of being at-risk, following them through the K-12 system; struggling to read and write. K-12 institutions and high education are addressing the issue of meeting the needs of the diverse learner.

According to Barbour (2009) the International Association for Online Learning K-12 (IAOL), suggest that:

"The majority of the literature may portray $K-12$ online learners as being primarily highly motivated, self-directed, self-disciplined, independent learners who read and write well, and who have a strong interest in or ability with technology. However, this is 
clearly not an accurate description of the entire or possibly even the majority of students attending virtual schools and, particularly, cyber schools." IAOL (p. 18)

The same manuscript reports, the U.S. Department of Education documents nationally, about 9\% or approximately 1.2 million U.S. students leave high school without obtaining a diploma every year. Barbour contends that some students fail or drop strictly for academic reasons, "others deal with personal/family circumstances, such as speaking English as a second language, moving frequently, having a teen pregnancy, or dealing with absentee parents." And that according to the National Dropout Prevention Center, "students who drop out often cite factors across multiple domains and there are complex interactions among risk factors". Many students with at-risk characteristics enter colleges and universities; yet, it is not known how many at-risk students nationwide from high schools enter colleges and universities. USA Today's writer Mary Beth Marklein reports that a recent survey issued to high school graduates found that the same set skills are needed if students enter the work force or college, however it was found that $42 \%$ of teachers reduce academic expectations for students who are not considered college bound... and in addition according to USA Today "Federal data show that fewer than $60 \%$ of new students graduate from four-year colleges in six years, and just one in three community college students earn a degree. More than 350,000 students who borrowed for college in 1995 had no degree six years later, according to a 2005 study for the National Center for Public Policy and Higher Education." Studies are continuously reasoning why the high attrition rates in colleges and universities and how to resolve the concerns. In addition the National Center for Public Policy report, authored by Venezia, A., Callan, P.M., Finney J.E., Kirst, M. W., Usdan, M.D., conducted interviews in Florida, Georgia, New York, and Oregon to determine student readiness for college and concluded many programs are successful. Georgia, the primary base of this paper, is noted in the report, as being cited as being one of the nation's leaders in the area of $\mathrm{P}-16$ reform that bridge gaps in learning for achievers and at-risk students. In the $\mathrm{P}-16$ office, there are numerous projects, one is the Post-Secondary Readiness Enrichment Program an institutionally based, supplemental program that focus on increasing college readiness for students in grades 7 through 12 who are in atrisk. Other programs are The Partnership for Reform in Science and Mathematic, and Performance Assessment for Colleges and Technical Schools (PACTS). The programs focus on student preparation for college; and student learning and knowledge.

\section{Literature Review}

Time management is one of the key skills at-risk students must master for online classes; writing weekly topics, trying to analyze and articulate views and being active on weekly discussion board, are a bit challenging for any student, and even more so for at-risk students. Online classes require active written participation, keeping up with classmates, maneuvering through a system that is foreign to at-risk participants; this may bring up past class defeats and negative experiences for at-risk students. Writing, reading, and organizational skills are important factors in Elearning platforms, and students who are already challenged in their learning and study skills may become disenchanted and helpless and lost due to their lack of E-literacy skills. Research indicates that while at-risk students may lack literacy skills on-line, brick and mortar school, land classrooms often encourages improvement through routine classroom attendance; professor provide face to face strategies and interaction that motivate class attention, stimulation and at-times even embarrassment may leads a students to improve. There is social and cultural interaction that plays an important part in wanting to succeed in land classes. In E-learning classes at -risk students thirst for special attention; and unless some attention is given, it has been proven through research and in this writers art core classes that students may drift or withdraw.

In an article by Kimberly E. Arnold the author reports and assesses a program instituted by Purdue University that addresses intervention with at risk students in on-line, enhanced on-line and 
face to face. According to Arnold a team at Purdue University headed by John Campbell, Peter DeBlois, and Diana Oblinger developed a tool to identify at risk students and improve their learning outcomes. The Purdue project, called The Purdue Early Warning System (PAWS), is identified as Signals. The intervention project enrolls more than more than 11,000. The team identified and named three scenarios to improve learning outcomes.

Scenario 1: The technology of academic analytics will provide better and more actionable information. This information can, in real time, inform faculty interventions to increase student success in their courses

Scenario 2: Academic analytics will provide information that allows students to be more proactive about their learning behavior, empowering themselves.

Scenario 3: Academic analytics will allow advisors to see real-time performance across classes, soon enough in the semester to intervene. Once accessed, help resources can better track student usage and make more refined resources available as needed.

The program has over-whelming affected student success. Technology follow students from entry to end of their college years; faculty and staff provide intervention when necessary. The program has improvement in learning outcomes retention and attrition. Purdue identifies in their program

Students at risk

A variety of instructional services

Processes to restructure student orientation programs

Colleges and universities have gradually embraced the virtual classroom delivery for various reasons and some may not have initially been to improve pedagogy that they employ; many saw it as a means of economics, others as reaching a generation of working non-traditional population.

Many institutions and faculty frown on cyber education citing low quality teaching and learning; high attrition, poor out comes; however other advocate there is no difference in learning or attrition than in the brick and mortar classroom, as voiced by Robert W. Mendenhall, president of Western Governors University, in an article written for the Chronicle of Higher Education, "that the quality of education is largely independent of the mode of delivery." Mendenhall cites a report from the American Enterprise Institute called "Diploma and Dropouts" that used 1,300 colleges and universities with comparable characteristics in students. Fifty dropout factories were listed by The Washington Monthly's 2010 College Guide with graduation rates of 5 per cent and 20 percent. In comparison in a review of on-line learning published by the US Department of Education, it was concluded that "on-line learning was as good as or slightly more effective than traditional face to face instruction." (Governors University is a competency-based online university offering over 50 accredited online bachelor's and master's degree programs)..

Oblinger and Oblinger, editors of Educating the Net Generation, explore differences and challenges of the net generation. More specifically within the chapters as related to E-literacy and at risk students, Robert Kvavik studied responses from 4,374 students enrolled at 13 higher education institutions in 5 states. All students are reported to have had internet access, with at least 81 percent through commercial or university sources, and most resided on campus with ranking freshmen through seniors. Kvavik investigated the level of skills needed by students enrolled in partially or fully online classes. He surmised that in order for students to be successful they students needed two types: "information literacy or fluency and the technical skills needed to use the tools." The surveys issued to participants used the rating scale: 4(highly skilled) to 1(very unskilled). The scaled used assessed student perception of their technology skills.

Students responded high in understanding use for communications, word processing, and the Internet; averaging 3, e-mail, instant messenger, word processing, and Web surfing and accessing the on-line library, and course management systems fell just above 2.5 range. The survey did not 
take into consideration any at-risk population. However Kvavik noted a difference in the quantitative data and the qualitative interviews noting that student "skills seemed more problematic." The interviews indicated that students were "skilled with basic office suite applications but tend to know just enough technology functionality to accomplish their work.... they have less in-depth application knowledge or problem solving skills." The same article recognized another study with similar finding by Sharon Fass McEuen's study of student technology skills at Southwestern University in Georgetown, Texas; skill levels were highest in word processing, internet use and communications; and low in presentation software. She also found much lower levels of skill in the maintenance of computers. Kvavik quoted McEuen as using the analogy that "Students come to college knowing how to write, but they are not developed writers."

It was concluded by Kvavik that students overate their skills and "do not recognize the enhanced functionality of the applications they own and use." He further summarized that students' preferences for use of classes with partial or full technology did not differ. Students with low GPA or high GPA were not a significant factor.

In a study that spanned 2004 through 2008 involving seven community colleges to improve online grades and graduation rates found improvement in students who participated compared to those who didn't participate. Students were 9 per cent more likely to stay in school and 11 per cent more likely to increase their grade to A-C, and thus a 3 per cent better chance of graduating. The students participating, according to the article written by Josh Fischman in the special issues of The Chronicle of higher Education, are the first in their families to attend college. The article quotes Mr. McElroy, dean of retention stating "These are students who just don't have the tools to put themselves in the drive's seat". The intervention web program assess the learning styles of atrisk students; determine if they learn best through visuals, hands on or reading. The program directs the student to counselors, instructors when alerts flag the student as having trouble. The same article addresses community colleges retention and cites a 2010 report by ACT, the nonprofit education-assessment organization, "What Works in Student Retention." According to Fischman, ACT 305 colleges and reported "the leading reason for attrition were a student's lack of readiness for college-level work, deficient study skills and money problems.

Being able to maneuver through a Learning management system and use all components integrated in the system increases understanding of the lesson through a diverse approach and the number of resources for comprehending what the lesson entails. In a survey measuring LMS tools used by instructors, Curtis J. Bonk found that only 23-45 percent of online instructors surveyed actually used online activities related to critical and creative thinking, hands-on performances, interactive labs, data analysis, and scientific simulations. However, forty percent of the participants said those activities were highly important in online learning environments.

In another study Penagitakopolos and Vergidis (2004) examined the topic of online dropouts, a comparison of two classes that included over 1230 undergraduates of which 349 dropped. Their findings indicated there was a larger percentage $57.4 \%$ of drops of students who were first year students, the remainder ranged in age 30-39. The team surmised that the first-time students had not adjusted to college study and the second and older group had occupational obligations.

The National Center for Education Statistics analyzed data from a 2004-2006 survey that measured reasons cited for leaving college. The study looked at percentage for leaving among 20032004 students who left postsecondary education as of 2004 with no degree or certificate by Community College Taxonomy: 2006. The highest reason cited was the study indicates that personal reasons at 48.8 and secondly 29.8 other unspecified reasons and Financial reasons at 29.1; family reasons at 16.9; followed by dissatisfaction with the program at 11.9 and Academic 12.3 and scheduling problems 9. Non-traditional students with greater responsibilities ranked high as being more likely to leave college. The study further indicates that community college students 
who obtain a AA degree are more like to receive a bachelor's degree and than students who transfer to four year institutions prior to receiving AA degrees. There also seemed to have been a correlation between transfer AA degree students' persistence to meet goals and receiving a bachelors degree.

\section{Generation Z the Digital Natives}

College and university students are highly connected to the world with their various communication gadgets. The baby boomers and generation $X$ were glued to their computers fascinated over word processing and e-mail. Generation $\mathrm{Z}$ surpasses in the previous generations with their plethora of social tools: use of instant messaging, text messaging, twitter, Facebook, Skype, World Wide Web, smart phones, iphones, ipods, iTunes, note pads, lap computers, You Tube and the latest invention by Apple Inc. the $4 \mathrm{G}$ iPad having all the feature a student needs using just a slight tip of a finger and a spin. The technological savvy $\mathrm{Z}$ generation has been referred to by many names because of their confidence with technology:

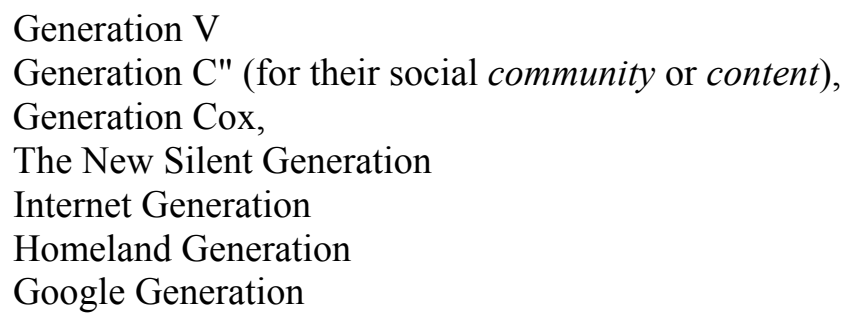

One would suspect that this generation with so many disambiguated references of their title would have superior advances with any learning management system. It seems that they would be literate in E-learning; understanding how to locate, maneuver and understand symbols and instructions; however this is not the case. Students today use technology to communicate with parents, family and friends. Hence, technology serves a very important part in the daily lives but not as an academic tool. In many cases E-learning is viewed by at-risk students as a different type of technology. One of the reasons for viewing learning management systems as foreign is that Elearning technology has not been marketed on campuses as user friendly; and having not been properly implemented as a beneficial learning resource that incorporates social media, at-risk students enters the cyber class web page and freezes. They become overwhelmed and stressed viewing the many icons. Counseling students about the positive learning effects of on-line learning will reducing at-risk students stress level with learning management systems. According to Stephen Abram, four year institution students are more equipped to learn from learning management system and they lead society in use with technical gadgets, however "community college students do not use digital tools as much as four-year college students and graduate students. Abram reports that Pew Research Center's Internet \& American Life Project confirms that undergraduate and graduate students - are more likely to use the Internet and their own tech devices than the rest of the general population. Comparing college students with non-students ages 18 to 24 Abram found that students not attending colleges are more active on social networks, and send more updates to Facebook and Twitter. Chart s I, II, and III are surveys given by the Pew Internet and the American Life Project depicts the life style of the typical college student engaged with technology. The survey illustrated by Smith, Raine, and Zickuhr (2011), in an article title College Students and Technology, gives an overview of four year undergraduate students' use of computers showing slightly more usage than community college students. This may be due to the fact that generally community college students are from a lower social and economic group and have not been exposed to computers and are not as college ready academically as the general four year student entering from high school. Even less prepared are certain cultures that fall under the lower economic and social class. According to an article by staff writers for Online Colleges, 17 
Scary Stats on Minority Education in America, "Hispanic and black students are less likely to have internet access at home. Because of this, they adapt to classroom technology at a slower pace than their white, Asian and Native American peers. Twenty-six percent of Hispanic and 27\% of black students use the internet at home, compared to $58 \%$ of Asian and $47 \%$ of Native American kids, resulting in a very unfortunate achievement gap." Chart I in Smith et al. report substantiates this finding under the Pew Internet Project. Chart II verifies that college students although busily engaged and connected socially, non college student networking is more active. In comparison to advance students, $88 \%$ of non-students use social network media compared to $86 \%$ of graduate students, a close second. This may be attributed to the fact that non college students in the same age group as undergraduate have more time and many of there friends are not found in arms reach or within an accessible social setting, like a campus; comparatively graduate students are older and their network is more expansive and beyond a campus with added responsibilities and research for collective involvement. The survey substantiates great social use but not academic usage.

Chart I (Source: Pew Internet Project, July 19, 2011).

\section{College students and their gadgets}

Percentage of all adults in each group who own different devices

\begin{tabular}{|lccccc|}
\hline & $\begin{array}{c}\text { All } \\
\text { adults }\end{array}$ & $\begin{array}{c}\text { Non- } \\
\text { students, } \\
\mathbf{1 8 - 2 4}\end{array}$ & Undergrads & $\begin{array}{c}\text { Grad } \\
\text { students }\end{array}$ & $\begin{array}{c}\text { Community } \\
\text { College }\end{array}$ \\
\hline Cell phone & $82 \%$ & $89 \%$ & $96 \%$ & $99 \%$ & $94 \%$ \\
\hline Desktop computer & 60 & 58 & 59 & 73 & 67 \\
\hline Laptop computer & 52 & 64 & 88 & 93 & 70 \\
\hline iPod or mp3 player & 45 & 69 & 84 & 86 & 72 \\
\hline Game console & 41 & 64 & 58 & 49 & 61 \\
\hline e-book reader & 5 & 4 & 9 & 7 & 4 \\
\hline Tablet computer & 4 & 4 & 5 & 5 & 4 \\
\hline
\end{tabular}

Source: Pew Research Center's Internet \& American Life Project 2010 tracking surveys. All include landline and cell phone interviews. $\mathrm{N}$ for all adults $=9,769 ; \mathrm{n}$ for $18-24$ year old non-students $=717 ; \mathrm{n}$ for four-year undergrads $=246, \mathrm{n}$ for grad students $=112, \mathrm{n}$ for community college students $=164$.

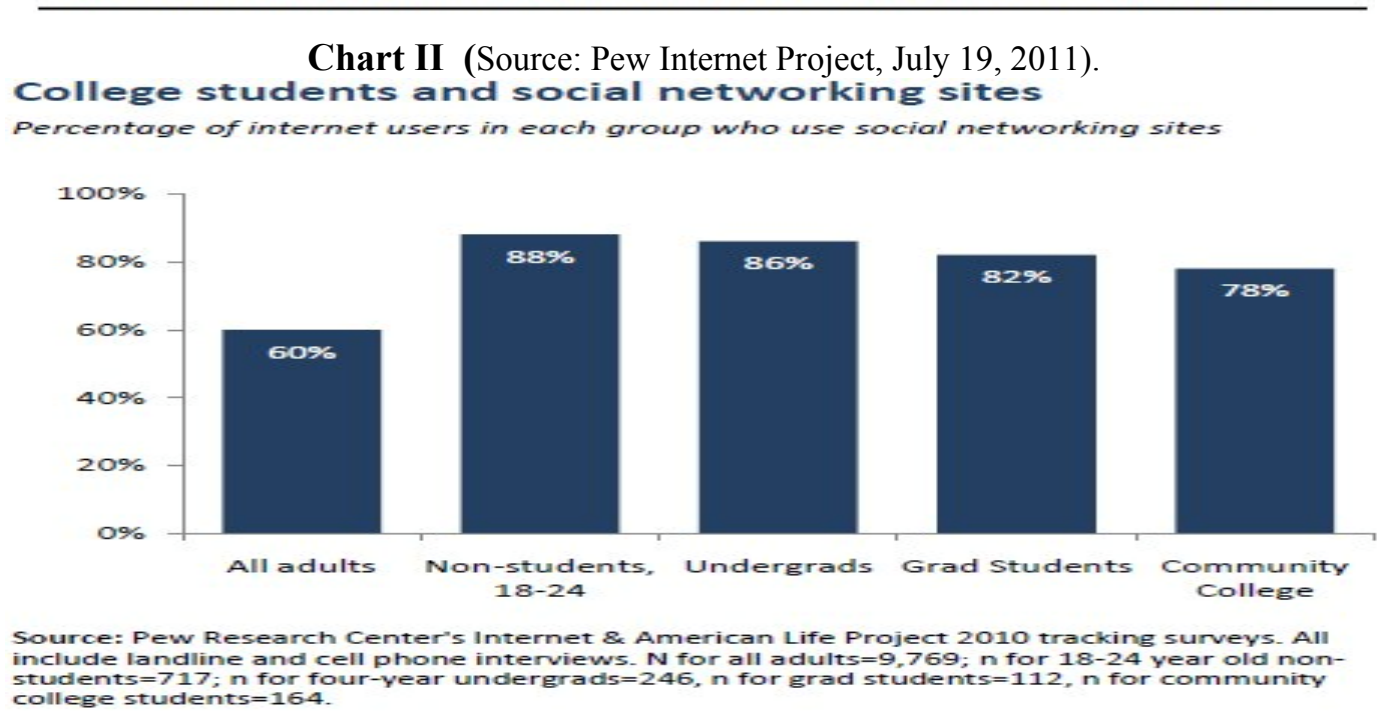


Chart III demonstrates the wide acceptance of the internet in the US and the availability of broadband and wireless systems across the populous. According to Smith, Raine, and Zickuhr (2011) in an article title College Students and Technology college students use more internet than the general population. It is expected that students would have a higher usage of the internet at $98 \%$ compared to the general public at $75 \%$. Students are actively engaged in research for classes and have a high social network. In Chart III undergraduate and graduate broadband users exceed the general public much greater percentage and plummets' in comparison with the use of wireless connections. Pew surveys have established high internet usage among college age students; however the virtue classroom room requires a different type of attention span, knowledge and skills in order to perform successfully.

Chart III College Students and Technology (Source: Pew Internet Project, July 19, 2011).

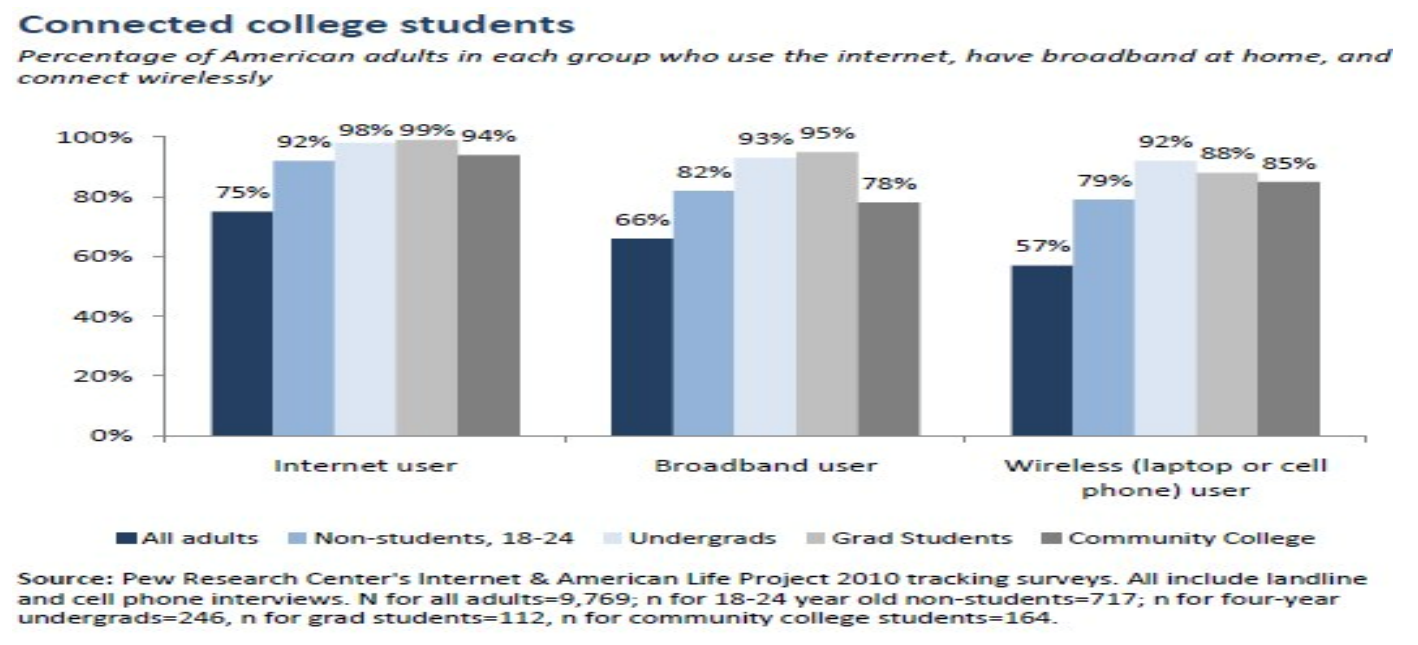

Mary Helen Miller, in an article titled How Interactive Technology Can Help Minority Students, interviewed James L. Ellenson, who teaches at a historical black university, North Carolina Central University. Ellenson discusses his view point from his classroom experience and interaction with black students. He states that minority students are often hesitant "because you'll suffer some social consequences for that. Even more insidious is the fear of being right.

The social pressures are such that standing out as an academic performer is apparently not as admired as (for example) athletics. If they answer questions correctly in classrooms, many at-risk students may lose friends because they have strayed from the norm by "acting smart'. Many atrisk students are first generation attending college and thus have no academic direction from parents who may serve as a foundation for advising and/or developing academic habits. At-risk students may not have the encouragement or role model from home, many come from single head of house holds and parents may have been working two or three jobs. Many at-risk students have little time to develop study skills or academic habits where the main focus is to survive, secure food, and pay bills. American Council on Education has identified indicators that may determine students' persistence in staying in college. Table I compares students ethnicity with positive and/or negative predictors of obtaining a bachelors degree. African Americans students attending college full time and with at-least one parents who has attained a bachelors' degree are more likely to complete college. 
Table I Factors Influencing Student Persistence to stay enrolled, by Race/Ethnicity

\begin{tabular}{|l|l|l|}
\hline Student Race Ethnicity & $\begin{array}{l}\text { Positive Predictors of } \\
\text { Obtaining a Bachelor's } \\
\text { Degree }\end{array}$ & $\begin{array}{l}\text { Negative Predictors of Obtaining a } \\
\text { Bachelor's Degree }\end{array}$ \\
\hline African American & $\begin{array}{l}\text { At least one parent with a } \\
\text { bachelor's degree or higher, } \\
\text { full-time attendance, grant } \\
\text { aid of more than \$5,000, } \\
\text { working 14 hours or fewer a } \\
\text { week, and majoring in health. }\end{array}$ & $\begin{array}{l}\text { Taking a "not rigorous" high } \\
\text { school curriculum, and delaying } \\
\text { enrollment. }\end{array}$ \\
\hline Asian American & $\begin{array}{l}\text { Taking a "new basics" high school } \\
\text { attendee, full-time } \\
\text { attendance, and grant aid of } \\
\text { more than } \\
\text { \$5,000. }\end{array}$ & $\begin{array}{l}\text { Not first-generation college and working 15 hours } \\
\text { attendee, full-time } \\
\text { attendance, and grant aid of } \\
\text { more than \$5,000. }\end{array}$ \\
\hline Hispanic & $\begin{array}{l}\text { Did not take "highly rigorous" } \\
\text { high school curriculum, low } \\
\text { parental income, and working 15 } \\
\text { hours or more a week. }\end{array}$ \\
\hline
\end{tabular}

Source: American Council on Education, (March 2006)

Based on the assumption that technology may be a medium to improve at-risk performance and give them a platform to speak without social repercussions; in order for at-risk students to be successful students need to be trained through an online orientation course on how to locate information within the lesson and use in the virtue on-library, available online technical support, online tutorial. E-literacy is more than just being able to read tools and comprehend lesson, it is about being able to construct meaning, relate for better understanding, organize and create. Students need to be able to do things like gain meaning from "pictures to help construct meaning, making predictions, rereading, segmenting and blending phonemes, and finding familiar word chunks to decode words" (Fisher, 2008), and more importantly discern whether the information is research/fact based or opinion based on the internet. Eshet-Alkalai and Chajut concurs suggesting digital literacy extends beyond the ability of the mechanics

\section{E-literacy Approach for At Risk Students}

Some responsibility of success is not totally on the student's back; faculty, academic institutions and LMS delivery systems hold some responsibility in assuaging at-risk students are successful in online courses. Some students' inattentiveness, just as in a face to face class, is due to not being stimulated by the wordy or the interactive platform. Research indicates that in the brick and mortar classroom at-risk students' needs are satisfied on many levels with several engaged activities. Professors provide face to face student learning strategies with visual facial and body stimulation, and that classroom social and cultural interaction that gives immediate satisfaction. In E-learning classes, unless there is consistent communication and interventions, at-risk students are at a disadvantage and will thirst for that special attention. Without the attention at-risk students may slowly drift or fall to the side and drop. According to Bonk (2004), effective E-learning environment need to facilitate student engagement with a community of learners, and that most online courses, programs, and resources still lack sufficient interactivity and collaboration needed to effectively engage online learners. Consequently, there is a pressing need for advice on how to create exciting and relevant online materials. "At-risk students thirst for online ...instructional activities which are fresh, innovative, and engaging. ... and that most online learning technologies 
are designed for the management of learners online, not for online learners to manage their own learning." At-risk students are most likely to crave for exciting visual interaction in on-line classes. In an art course student expect the bell and whistles with multi visuals and interactive tools that helps to maintain their attention span. At-risk students also need tools in E-learning environments that are easy to maneuver and visually understood and accessible. Many times students have voiced distress that they couldn't locate items on the homepage or display panel, this is usually due to the muted grey colors in the panel. Color has been proven to affect the right and left brain in stimulating learning. E-learning requires students to engage their left brain, the academic side, and the creative visual side. For example: The warm hue of orange and yellow are friendly happy and uplifting. According to Oracle Think Quest Education Foundation, these colors are "associated with intellectual thinking: discernment, memory, clear thinking, decisionmaking and good judgment. Also aiding organization, understanding of different points of view. Yellow builds self-confidence and encourages optimism. (However, a dull yellow can bring on feelings of fear)," while a limited amount of blue inspires mental control, clarity and creativity. What if a combination of these colors were used on LMS web pages as students proceeded to locate information?

It is important that the instructor visualize online classes as a diverse cyber rooms by using all the sources and course tools listed to assist with student learning (resources, assignments, tests, etc) so relationships are understood how each interact and supplement the learning process. In order to reach At-risk students they must feel free to actively engage in the system, this will lead to better understanding of the course, the platform, and pedagogical processes. At-risk students, coming from insecure environments need a secure controlled environment in order to be confident, this leads to greater participation and success. Students who are at-risk are able to learn on-line with all systems in place. In an evaluative data report discussed by Kuh, Kinzie, Buckley, Bridges, \& Hayek (2006) it was suggested that when used appropriately, information technology can be a solution rather than an obstacle to increasing success for underserved students. The key word is used appropriately by faculty member and student.

In the zest to offer online classes many institutions neglected to think about their diverse population of learners, and faculty who were not adaptable to teaching online. Later, few faculty, in comparison, were appropriately trained in how to use the medium or teach and interact online with students. Figure 1 below addresses faculty computer knowledge. In a survey issued by Kim and Bonk (2006), faculty "respondents' experience with online teaching varied from none to more than 10 years," with most experience using computers in blended classroom learning and a staggering low percentage in comparison for faculty with experience in fully engaged in E-learning.

In a survey measuring LMS tools used by instructors, Kim and Bonk found that only 23-45 percent of online instructors surveyed actually used online activities related to critical and creative thinking, hands-on performances, interaction. National concern has captured the attention of the US Department of Education and Commissions for accrediting colleges and schools:
Middle States Association of Colleges and Schools
New England Association of Schools and Colleges
North Central Association of Colleges and Schools
Northwest Accreditation Commission
Western Association of Schools and Colleges
Southern Association of Colleges and Schools

The US Department has issued new regulations for online education and has placed demands on accrediting commissions to hold institutions to high standards in order to assure that outcomes are no different in face to face courses than in distant education classes. The accrediting agencies adopted in 2001 guidelines for online best practices and made revision in 2006 recommending 
"that colleges show evidence that faculty members who teach online courses have been trained to use the medium, and that student support services are sufficient" (Kelderman 2011). Furthermore, training is only one step to assure faculty understands best practices for teaching a diversified class; continued classroom monitoring will assure at-risk students are moving forward in meeting outcomes. Kim and Bonk express a major concern over faculty readiness to teach fully engaged on-line courses. A survey taken by the team, results depicted in Figure 1, suggests the magnitude of Kim and Bonk concern. Many faculty teaching online courses may understand the content but not how to teach diverse learners or at-risk students online. Without understanding that many atrisk students need some type of institutional intervention process, retention and grade failure will continue to be a major problem in online education. The problem is not just learning the mechanics; it is also delivery of course content and interfacing with students online. If the student has no interaction with faculty and other students; and faculty does not give clear and precise thorough feedback with examples, at-risk students will see the assignments and activities as too burdensome and frustration will set in before content learning has a chance. According to Kim and Bonk bored students drop out of online classes for richer and more engaging learning experiences. This may be resulting from professor having inexperience with fully emerged on-line teaching, for example, in the survey taken by mostly college and university professors, Kim and Bonk discovered that most professor have little to no experience teaching fully online courses. The surveyors content that the majority ( 87 percent) of the professors stated that although their institution offered on-line courses their experience with fully emerged online teaching was limited. Figure 1, provided by Kim and Bonk, shows a variation from none to more than ten years. The graph shows an interest but more experience with integrating computers or technology enhanced classes. This study may also conclude that teachers inexperienced with online processes, procedures, pedagogy best practices will likely have uninterested and disengaged at-risk college students that's "checking-out" in the virtual class room. Instructor readiness to teach at-risk students is a challenge in any classroom, but on-line, the challenge is much greater in magnitude. There is no face to face interaction of attention that may result in peer and social interaction. Professors

\section{Figure 1}

Years of Experience with Online Teaching

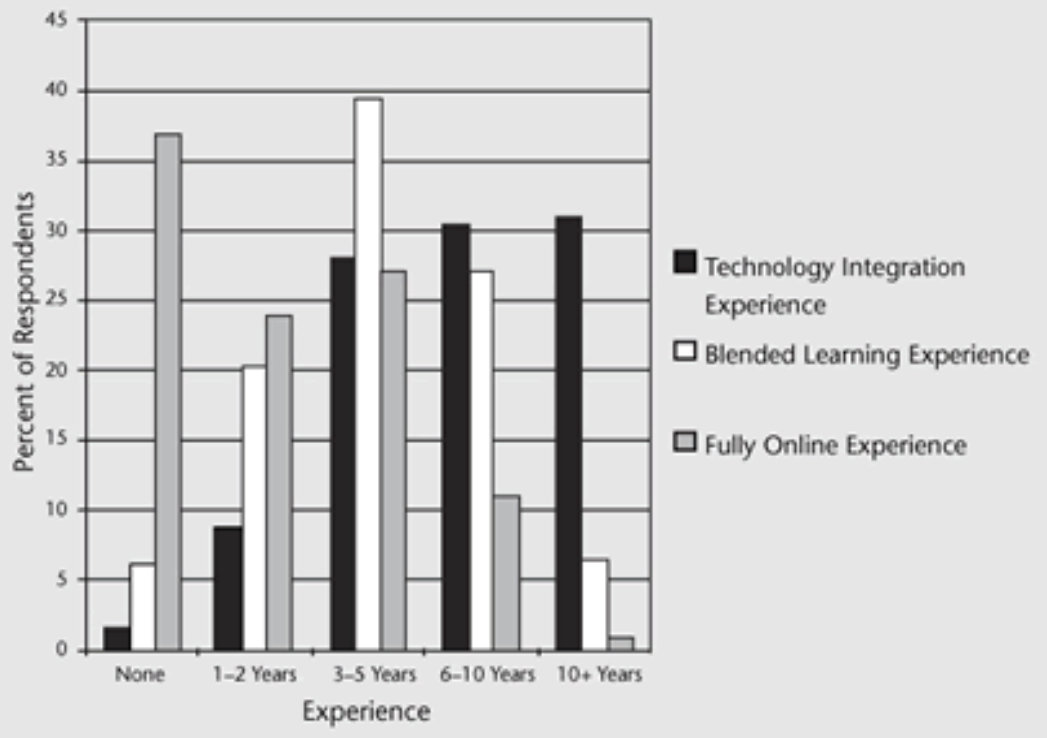

Figure 1. On Line Professor Readiness

Source: EQ Educause Quarterly, Kyong-Jee Kim and Curtis J. Bonk (2006) 
must go beyond the normal intervention that is required in brick and mortar environment. In spite of this, selected diversified class activities, continuous interventions with experienced staff and professors; on-line classes may engage at-risk students by giving them self- paced study, individualized attention. These personal and academic interventions will develop confidence within the student without having to hide from peers or face peer repercussions based on performance.

\section{Assessing Progress and Intervention}

Professor are constantly using ongoing formative assessments in cyber classes to assess student learning but seldom develop on-line courses content to reach diverse learning or at-risk groups. Students falling in the at-risk category need continuous practice, review, and assessment; ongoing assessment helps to determine student strengths and weaknesses. This requires fitting the LMS and/or content delivery to the type of students served not students fitting to the system. According to Woodill (2011) and Mayer (2005) "People can learn more deeply from words and pictures than from words alone." By "words" Mayer means either text or spoken words, and by "pictures" he means illustrations, photos, animations, or video." Epic LMS, is an example of a comprehensive instructional system integrating online student learning with faculty control and academic support. Epic audio videos integrate text within the videos and alongside visuals. This gives at-risk students a simulation of the face to face visual assurance that is similar to brick and mortar classes, alone with academic support provided.

For several years the writer was puzzled as to why so many students were dropping or failing in her class. In classes of 35 approximately $25 \%$ - $30 \%$ would either receive a failing grade or withdrawing. As a faculty member in a historical black institution, who had pride and a reputation of students learning in the face to face environment, this was a major concern. It was obvious some type of intervention was required above and beyond the norm. It was understood that many variable come into play when trying to seek rationalize for something that required additional understanding. Over a five year period the writer invested in learning what worked and didn't work with students who were defined as at-risk after the first week of class. The positions undertaken were to look reasons why students may be failing: the lay out of the class: fonts, color, ease of reading and understanding instructional materials assignments, and exams. Students' transcript records were studied and habits (how many face to face withdraws, " $D$ " and " $F$ " grades, successful grades and the subjects ("As", "Bs" and "Cs"). Writing examples were collected and studied and speaking to students on phone, office and through e-mail.

A large percentage of students enrolling into on-line classes were students were :

first generation college students

Students with poor study habits,

Developmental disabled students,

Student with poor reading and writing skills,

Students taking class with no intention of learning but to only collect on financial aid.

At -risk students attending the classes under study have many of the problems and challenges cited in this manuscript. The institution under study, Savannah State University (SSU) does not have an open admission policy, under which virtually all secondary school graduated or students with GED equivalency diplomas are admitted without regard to academic record, test scores, or other qualifications. According to the institution students lacking complete college-preparatory requirements are admitted on a provisional basis. The Relative importance of academic factors in first-time, first-year, degree-seeking (freshmen) admission decisions is indicate by check marks. (Non-academic factors are not required or considered.). Chart IV and V, based on 2006 data, indicate that students' academic records are one of the major considerations for admission; SAT and ACT scores are considered as well. It must be noted however, that the institution does use SAT I, SAT II or ACT scores in admission decisions for first-time, first-year, degree-seeking ap- 
plicants. This implies that many students although may have obtained the academic grade record to enter college they may fall short on comprehensive or literacy skills demonstrated on ACT and SAT assessments. Such literacy skills are predictors for success in an on-line class.

Chart IV The Relative importance of academic factors in first-time, first-year, degree-seeking (freshmen) admission decisions is indicate by check marks.

(Non-academic factors are not required or considered.)

\begin{tabular}{|c|c|c|c|c|}
\hline & Very important & Important & Considered & $\begin{array}{c}\text { Not } \\
\text { Considered }\end{array}$ \\
\hline \multicolumn{5}{|l|}{ Academic } \\
\hline Secondary School record & $\mathrm{X}$ & & & \\
\hline Class Rank & & & & $\mathrm{X}$ \\
\hline Recommendation(s) & & & & $\mathrm{X}$ \\
\hline Standardized test scores & $\mathrm{X}$ & & & \\
\hline Essay & & & & $\mathrm{X}$ \\
\hline
\end{tabular}

Source: Savannah State University: Institutional Planning and Assessment (2006)

\section{SAT and ACT Policies}

Indicators in Chart V shows that entrance exams are considered but are not the only indicator, SAT I, SAT II or ACT scores in admission decisions for first-time, first-year, degree-seeking applicants. Check marks in the cells below reflect institutions policy for use in admission.

Chart V General Admission Requirements for Students Enrolled in Courses

\begin{tabular}{|c|c|c|c|c|c|}
\hline & Required & Recommended & $\begin{array}{c}\text { Require } \\
\text { for } \\
\text { Some }\end{array}$ & $\begin{array}{l}\text { Considere } \\
\mathrm{d} \text { if } \\
\text { submitted }\end{array}$ & $\begin{array}{l}\text { Not } \\
\text { Used }\end{array}$ \\
\hline SAT I & & & & $\mathrm{X}$ & \\
\hline $\mathrm{ACT}$ & & & & $X$ & \\
\hline \multicolumn{6}{|l|}{ SAT I or ACT (no preference) } \\
\hline SAT I or ACT-SAT I preferred & $\mathrm{X}$ & & $\mathrm{X}$ & & \\
\hline \multicolumn{6}{|l|}{ SAT I and SAT II } \\
\hline \multicolumn{6}{|l|}{ SAT I and SAT II or ACT } \\
\hline SAT II & & & $\mathrm{X}$ & & \\
\hline
\end{tabular}

The institution use applicants' test scores for both placement and for counseling.

Source: Savannah State University: Institutional Planning and Assessment (2006)

Based on the charts above some intervention will be needed by students entering the institution. Kuh, Kinzie, Buckley, Bridges, \& Hayek (2006) early intervention is necessary when students enter colleges with certain deficiencies. Kuh et al. suggest the following principles for designing student success interventions:

- Rely on proven research,

- Suit needs of campus,

- Institutionalize the activity or service or program,

- Involve a variety of groups on campus,

- Be sensitive to change issue and retrain staff,

- Focus on students,

- Plan for sustainability regarding funding,

- Conduct assessment and institutional research,

- Be patient, and 
- Target the most needy student populations.

- Encourage faculty members to focus on deep learning activities.

For on-line classes faculty must design classes to reach a diverse group, providing higher levels of student to faculty and student to student engagement and assignments requires synthesizing information from different components used in the platform.

Before starting an on-line class it is good to know the profile of the students. According to SSU the percentages of the students enrolled in degree-seeking full-time and part-time, first-time, first-year (freshman) students enrolled in the fall term, including students who began studies during summer, international students/nonresident aliens, and students admitted under special arrangements are in partial in the charts below; including the percent and number of first-time, firstyear freshman enrolled in the fall who submitted national standardized (SAT) test scores.

Chart VI and VII Include information for all enrolled, first-time, first-year freshman degreeseeking students who submitted test scores. Partial test scores (e.g., mathematics scores but not verbal for a category of students) or combined other standardized test results (such as TOEFL) are not included in the chart below. SAT scores are re-centered scores. The 25 th percentile is the score that 25 percent scored at or below; the 75 th percentile score is the one that 25 percent scored at or above as indicated in Chart VII.

\section{Chart VI. First Time, First Year Admission-average SAT and ACT scores}

\begin{tabular}{|lcc|}
\hline & Percent submitting & Number \\
& Fall, 2006 & submitting Fall, \\
& & 2006 \\
SAT scores & 77 & 590 \\
ACT scores & 38 & 289 \\
& \\
\hline
\end{tabular}

Chart VII. First Time, First Year Admission-average SAT and ACT scores

\begin{tabular}{|lcc|}
\hline Fall, 2006 & 25th Percentile & 75th Percentile \\
SAT I Verbal & 410 & 480 \\
SAT I Math & 400 & 480 \\
ACT Composite & $160(?)$ & 190 \\
\hline
\end{tabular}

Source: Savannah State University: Institutional Planning and Assessment (2006)

Chart VIII. Percent of first-time, first-year freshman with scores in each range.

\begin{tabular}{|lll|}
\hline Fall, 2006 & \multicolumn{1}{c}{ SAT I Verbal } & \multicolumn{1}{c|}{ SAT I Math } \\
$700-800$ & $0 \%$ & $0 \%$ \\
$600-699$ & $2 \%$ & $2 \%$ \\
$500-599$ & $16 \%$ & $17 \%$ \\
$400-499$ & $61 \%$ & $58 \%$ \\
$300-399$ & $20 \%$ & $22 \%$ \\
$200-299$ & $1 \%$ & $2 \%$ \\
\hline
\end{tabular}

Source: Savannah State University: Institutional Planning and Assessment (2006) 
Many colleges and universities rely on the composite ACT (the American College Testing) and SAT (Scholastic American Testing) scores as indicators of success in college. In a paper by Bettinger, Evans and Pope the team found that the four sub tests of the ACT only two are predicative of how a student may be successful in college. They content that English and Mathematics, are highly predictive of positive college outcomes while the other two subtests, Science and Reading, provide little or no additional predictive power. The study indicates the same predicts success retention and who will drop by the first and third year. Although data was not available for ACT subtests SAT indicators in Chart VIII shows an interesting parallel in scoring (the average national subtest score is approximately 500 for SAT). The validity of tests has been questioned for decades as inadequate indicators for performance measures. Chart VIII, if used as a valid indicator for SAT suggest students at SSU scoring approximately $18 \%$ in Verbal and Math, average and moderate, would succeed and approximately $61 \%-58 \%$ low, the majority would have challenges. However this is not the case; and in contrast Chart IX indicates that over $90 \%$ admitted to SSU have earned at least a $\mathrm{C}$ or above on their overall report cards. Historically, institutions like SSU are rich in tradition, serving the underprivileged and first generation college students. These institutions transform questionable students into top leaders and productive citizens. The philosophy behind looking at more than ACT and SAT scores are rooted deep into the mission of providing opportunities to students that may not have a chance for collegiate success. The multiracial and ethnic groups attending Historically Black Colleges and Universities (HBCU) come to obtain personal academic and social support that may not be equally available in quality at other institutions. In fact according to Kuh et al., "HBCUs appear to connect students and faculty in ways that increase students' level of engagement and commitment to success. This combination of clarity of mission, talent development philosophy, and supportive campus climate helps these institutions to overcome substantial financial and physical plant inequalities to foster student success."

\section{Chart IX. High School Report Card Consideration for Admission}

\begin{tabular}{|l|c|}
\hline Fall, 2006 & \multirow{2}{*}{30} \\
\hline Percent with HS GPA of 3.0 and higher: & 66 \\
\hline Percent with HS GPA between 2.0 and 2.9: & 1 \\
\hline Percent with HS GPA between 1.0 and 1.99: & 0 \\
\hline Percent with HS GPA below 1.0: & 3 \\
\hline Percent who submitted NO GPA: & \\
\hline
\end{tabular}

Source: http://irp.savannahstate.edu/IRP/Common Data 2010/commondataC.htm http://www.act.org/newsroom/data/2011/pdf/profile/Georgia.pdf

Many HBCU at-risk students come from single female head of households, the lowest socioeconomic quartile, there is usually a pattern of siblings receiving poor grades, or attendance record is poor, and/or dropping out of high school. The behavior continues through college. Taking into consideration the culture of students the virtual class taught by this writer required redesigning. After redesigning the course to accommodate the vast differences in learning styles, a program of intervention was established. The interventions are listed below for each year. The sample courses pulled for this study are spring semester classes and sessions that seemed to have the most at-risk students based on GPA. Class challenges for enrolled at-risk students were.

Non-attendance

Limited assignment participation

No participation in discussion forum

Limited to no participation in chat-room (extra credit to visit faculty member tutorial sessions) 
No-shows for counseling

Missing most assignments and exams

No acknowledgement receiving intervention letter

No acknowledgement receiving e-mails

\section{Chart X. Sample Class Spring 2006 (before redesign)}

$\begin{array}{lll}\text { Mid Term } & 2006 & \text { Final Grades }\end{array}$

\begin{tabular}{|l|l|l|l|l|l|l|l|l|l|l|l|l|}
\hline A & B & C & D & F & W & $\begin{array}{l}\text { Intervention } \\
\text { (NA) }\end{array}$ & A & B & C & D & F & W \\
\hline 2 & 8 & 3 & 4 & 9 & 12 & NA/Enroll 38 & 6 & 4 & 6 & 3 & 7 & 12 \\
\hline & & & & & & $\mathbf{2 0 0 7}$ & & & & & & \\
\hline 4 & 6 & 2 & 1 & 0 & 1 & NA Enroll 14 & 5 & 6 & 3 & & 0 & 0 \\
\hline & & & & & & 200840 & & & & & & \\
\hline & & & & & & NA & & & & & & \\
\hline
\end{tabular}

Chart XI, Sample Class (after redesign and intervention strategies)

Mid Term

2009

Final Grades

\begin{tabular}{|c|c|c|c|c|c|l|l|l|l|l|l|l|}
\hline A & B & C & D & F & W & $\begin{array}{l}\text { Intervention } \\
\text { Enrollment 32 }\end{array}$ & A & B & C & D & F & W \\
\hline 2 & 5 & 8 & 5 & 7 & 5 & $\begin{array}{l}\text { e-mails and face to face } \\
\text { Counseling, opportunity to } \\
\text { redo assignments }\end{array}$ & 3 & 7 & 10 & 2 & 5 & 5 \\
\hline 0 & 9 & 17 & 7 & 6 & 4 & $\begin{array}{l}\text { e-mails and face to face } \\
\text { Counseling, opportunity to } \\
\text { redo assignments }\end{array}$ & 4 & 8 & 16 & 5 & 4 & 6 \\
\hline 3 & 9 & 6 & 3 & 7 & 6 & $\begin{array}{l}\text { e-mails and face to face } \\
\text { Counseling, opportunity to } \\
\text { redo assignments and tests }\end{array}$ & 3 & 5 & 10 & 2 & 8 & 6 \\
\hline 2 & 1 & 10 & 4 & 15 & 5 & $\begin{array}{l}\text { Email sent every three } \\
\text { weeks, face to face and } \\
\text { intervention letter to use } \\
\text { services, opportunity to } \\
\text { turn late work in on } \\
\text { designated date. }\end{array}$ & 4 & 5 & 11 & 5 & 3 & 8 \\
\hline
\end{tabular}

Although there seems to be a marginal degree of success, some consideration must be given to the fact that after mid-term grades are received there are other variables that impact success. 1 . Many students improve based on the realization there is an official grade recoded; 2 . Some students take time to understand the material and processes; 3 . Others see intervention as an oppor- 
tunity, and 4. A few withdraw to improve their grade point average. The spring 2012 class was part of a national intervention project under American Public University System, Next Generation Learning Challenges to Enhance Student Outcomes through Sakai Learning Management System, Online Academic Analytics Initiative (OAAI) Grant Project lead by Marist College, Poughkeepsie, New York. The Sakia project included only hybrid courses that tracked student outcomes. The project identified freshmen and sophomore level students who tended to struggle for success The intervention strategies were identified as : class " $\mathrm{A}$ " received e-mail letters with campus services listed and requested students to make an appointment to see instructor, class " $\mathrm{B}$ " intervention, receives a letter inviting at-risk students to enter a web site for support and guidance. Class "C" had no special interventions. Chart XI, spring 2012, records intervention and grades from group " B".

Intervention resources are key elements in steering at-risk students; they need to know how to make meaning from different text forms and communication modes, how to communicate through those modes and how to use those media to learn, inform, investigate, reveal, advocate, and organize (Rheingold, 2009: Kajder, 2010). Kyong-Jee Kim and Curtis J. Bonk research confirms that pedagogical competencies of instructors are a major importance in student success and the second half is student E-literacy. The Sakai consortium open source course intervention points out the need to explore this national concern providing assistance for at-risk students to achieve course outcomes.

\section{Limitations and Implications}

There are a number of variables that interplay with why at-risk students may drop from on-line courses. Some students are at-risk prior to entering on-line courses due to poor study habits and thereby have little chance of succeeding regardless of interventions, others have personal and occupational conflicts. On-line courses provide a systematic way of learning, however as long as problems with at-risk students plague the virtual system there will be uncertainty among traditional public universities as to how swiftly they will introduce $100 \%$ on-line degree programs. An increased understanding through research will assure an appreciation of the many possibilities for future on-line education. Developing inter- related instructional programs similar to Sakai will open up possibilities for LMS to become more creative on how they address diverse challenged learners and how to assure their on-line E-literacy. There is also a particular need for special education challenged students and as research opens up different paradigms of interventions and tools on-line with open up a greater and more successful student who may be labeled as at-risked.

The development of voice tools in LMS could provide unique possibilities for at-risk student s to interface with peers and faculty in real time. "Deciphering" is the key to successful in E-literacy; recognizing format, deciding what to do with it while gaining a general understanding of the process. As mentioned above at-risk students should be e-literate in the 21 st Century cyber world and in general:

- Be literate in the subject matter.

- Possess ICT skills. This requires the skills necessary to use input devices such as a keyboard, mouse, trackball, and track pad. This also requires the knowledge and skill necessary to organize and retrieve computer files; to locate information from a variety of sources, and to critically evaluate the authenticity of information.

- Be independent or self-directed problem solvers (i.e., critical thinkers able to use higher order thinking skills). This requires abilities to question, hypothesize, analyze, evaluate, synthesize, strategize, plan, prioritize, implement, produce, and reflect.

- Possess social skills. This requires communication skills and the will to collaborate. 
- Be ethical, responsible, and accountable.

- Possess systemic thinking skills.

(Luterbach,2011)

There are many barriers for at-risk learners to overcome. Many have poor study habits that require either a remedial attention or tutorial assistance. The desire to learn and attend college must be an individual goal of a student. Attending a higher education institution to satisfy parents, play a sport, find a spouse, or pay bills through financial aid will not lead to successful outcomes. Many at-risk students enrolled in online classes and value the experience, they work hard and avail themselves to all the services provided for them by an institution. Their college experiences are rich and memorable and are rewarded on graduation day.

First time students signing to enroll in online courses should be screened through an orientation course. The orientation should assess student's basic comprehension and understanding, and how to maneuver through the course. If students do not successfully pass the orientation course they should not have an option to enroll into an online course until they are successful with the orientation. If students are not successful in two on-line courses institutions need to consider limiting the number of online courses at-risk students are allowed to enroll. We must prepare students for a global life experience and higher education provides a venue for students to expand their knowledge and skills and prepare for a successful life. Preparing students does not mean traumatizing by placing them in situations where their knowledge or skill sets are not at a standard level to progressively learn and improve.

Studying five classes and intervening in most with various strategies have not resulted in major grade changes or commitment from at-risk students. But, it has brought to my attention that faculty cannot do intervention alone. Administration and staff must join with faculty to intervene when students are having problems. Working with at-risk students is a university commitment; and students must feel invested and committed to the process of learning.

The writer recommends greater involvement from institutional administration; develop a sound plan to trace at-risk students through their freshman year to the end of their 4 - 5 year learning experience, placing an available and accessible team to answer concerns and intervening throughout students' educational experience. Learner readiness involves more than access to computers. It also involves having access to technical support as well as other forms of student support - such as navigation tools and course management systems support, and the processes that enable students to gain literacy skills if they do not already possess them.

Purdue's Signal program seems to have a somewhat of handle on at-risk students intervention. Students are screened upon entering the university, and intervention starts day one for at-risk students and follows them throughout their 4-5 year learning period. Each professor in the student's program of learning (classes) writes a report at the end of the class and discusses the students' progress and challenges throughout the class. Included in the report are the number of times the student received advisement and what plans were discussed to improve. This journal from each class follows the student through graduation. Faculty are able to assist students at any given time by pulling student's file to review progress or to continue intervention on a particular challenge that has been outlined; intervention, planning and assessment are continues. There are many models to use as a guide, but it is clear the total institutions need to address the issue of meeting the needs of at-risk students taking on-line classes.

\section{References}

Abram, S. (July 28, 2011). New college students and technology. Stephen's Lighthouse. Retrieved from http://stephenslighthouse.com/2011/07/28/college-students-and-technology/ 
ACT Profile Report. (2011). Graduating class 2011, Georgia. ACT. Retrieved from http://www.act.org/newsroom/data/2011/pdf/profile/Georgia.pdf

Allen, E. I., \& Seaman, J. (2005) Growing by degrees: Online education in the United States, 2005. Needham, Mass.: The Sloan Consortium.

Anderson, E., \& Kim, D. (2006 March) Increasing the success of minority students in science and technology. American Council on Education. Retrieved from http://www.acenet.edu/AM/Template.cfm?Section=Publications\&Template=/CM/ContentDisplay.cfm $\underline{\& \text { ContentID }=28222}$

Archambault, L., Diamond, D. ,Coffey, M., Foures-Aalbu, D., Richardson, J., Zygouris-Coe, V., Brown, \& Cavanaugh, C. (2002). Research committee issues brief: An exploration of at-risk learners and online Education. International Association of K-12 Online Learning, INACOL Research Committee. Retrieved from http://www.inacol.org/research/docs/iNACOL_AtRiskStudentOnlineResearch.pdf

Arnold, K. (2010). Signals: Applying academic analytics. Education Quarterly, 33(1). Retrieved from Educause Quarterly Magazine Web site http://www.educause.edu/EDUCAUSE+Quarterly/EDUCAUSEQuarterlyMagazineVolum/SignalsApp lyingAcademicAnalyti/199385

Barbour, M. K. (2009). Today's student and virtual schooling: The reality, the challenges, the promise. Journal of Distance Learning, 13(1), 5-25.

Baron, J. (2011). E-mail notes to participants from Marist College. Marist College Poughkeepsie, New York.

Bettinger, E. Brent, E., \& Pope, D. (2011, May). Improving college performance and retention the easy way: Unpacking the ACT exam. The National Bureau of Economic Research. Retrieved from http://faculty.chicagobooth.edu/devin.pope/research/pdf/Final\%20AEJ\%20Paper.pdf

Bonk, C. J. (2004). The perfect e-storm: Emerging technologies, enhanced pedagogy, enormous learner demand, and erased budgets. London: The Observatory on Borderless Higher Education. Retrieved from http://www.publicationshare.com/part2.pdf

Campbell, J. (2011). Biography. AVP for IT Academic Technologies. Educause. Purdue University West Lafayette, Indiana. Retrieved from http://www.educause.edu/Community/MemDir/Profiles/JohnPCampbell/43157

Cook, B., \& Cordova, D. (2007). American Council on Education. Minorities in higher education. Twenty second annual status report: 2007 supplement. Retrieved from http://www.acenet.edu/AM/Template.cfm?Section=CAREE\&Template=/CM/ContentDisplay.cfm\&Co ntentID $=23716$

Cullen, T., \& Cobb, I. (2011). Computer literacy needs in a traditional library literacy program: Results of a needs analysis. TechTrends, 55(6), 25-32. Retrieved from ProQuest Education Journals. (Document ID: 2520235161).

Fischman, J. (2011, November). 7 Community colleges open an online doorway to better grades and graduation rates. The Chronicle of Higher Education. Online learning: How Effective is the virtual classroom. Section B.B14-15.

Fisher, D., Frey, N., \& Lapp, D. (2008). Shared readings: Modeling comprehension, vocabulary, text structures, and text features for older readers. The Reading Teacher, 61(8), 548-556. Retrieved from ProQuest Education Journals http://www.fisherandfrey.com/wp-content/uploads/2010/01/rt-sharedreading.pdf

Ford, M. P. (2005, December). Differentiation through flexible grouping: Successfully reaching all readers. Learning Point Associates. Retrieved from http://www.learningpt.org/pdfs/literacy/flexibleGrouping.pdf

Funk, J. (2005, August). At-risk online learners reducing barriers to success. Education and Technology in Perspective. Retrieved from eLearn magazine http://elearnmag.acm.org/featured.cfm?aid=1082221 


\section{E- literacy and At- Risk College Students}

Horn, L. \& Weko, T. (2009, July). On track to complete? A taxonomy of beginning community college students and their outcomes 3 years after enrolling: 2003-04 through 2006. IES National Center for Education Science. Retrieved from IES National Center for Education Statistics Web site http://nces.ed.gov/pubs2009/2009152.pdf

Jacobs, V. A. (2008). Adolescent literacy: Putting the crisis in context. Harvard Educational Review, 78(1). $7-40$.

Jones-Kavalier, B. R., \& Flannigan, S. I. (2008). Connecting the digital dots: Literacy of the $21^{\text {st }}$ Century. Teacher Librarian; February 2008; 35, 3; ProQuest Education Journals. 13 \& 16.

Johnson, B. (n. d.). 15 effective strategies of the National Dropout Prevention Center/Network as a model for plan development. A technical assistance document. Retrieved from http://www.ped.state.nm.us/SEB/technical/Dropout $\% 20$ Prevention\%20TA\%20Document $\% 20 \mathrm{BJ} \% 204$ $\underline{-6-}$

Kajder, S. (2010). Adolescents and digital literacies: Learning alongside our students. Urbana, IL: NCTE, 2010.

Kelderman, E. (2011). Online programs face new demands from accreditors. The Chronicle of Higher Education. Online learning: How Effective is the virtual classroom? Section B.B4-5.

Kim, K. J., \& Bonk, C. J. (2006). The future of online teaching and learning in higher education: A survey substantiates some ideas about online learning and refutes others. EDUCAUSE Quarterly, 29(4). . Retrieved from EQ magazine Web site http://www.educause.edu/EDUCAUSE+Quarterly/EDUCAUSEQuarterlyMagazineVolum/TheFutureo fOnlineTeachingandLe/157426

Kuh, G. D.,Kinzie, J., Buckley, J. A., Bridges, B. K., Hayek, J. C. (2006 July). What matters to student success: A review of the literature. National Postsecondary Education Cooperative (NPEC). Retrieved from the Commissioned Report for the National Symposium on Postsecondary Student Success: Spearheading a Dialog on Student Success http://nces.ed.gov/npec/pdf/kuh_team_report.pdf

Learning Point Associates (2004). A closer look at the five essential components of effective reading instruction: A Review of scientifically based reading research for teachers. Retrieved April 19 from http://www.learningpt.org/pdfs/literacy/components.pdf

Luterbach, J. L., \& Brown, C. (2011). Education for the 21st Century. International Journal of Applied Educational Studies, 11(1), 14, 19.

Mayer, R. (Ed.) (2005). The Cambridge handbook of multimedia learning. New York: Cambridge University Press.

Marklein, M. (2010, March 16). What if a college education just isn't for everyone? USA Today. Retrieved from USA Today web site http://www.usatoday.com/news/education/2010-03-161Acollegeforall16_CV_N.htm

Mendenhall, R. W. (2011, November). How technology can improve online learning-and learning in general. The Chronicle of Higher Education. Online Learning: How Effective Is the Virtual Classroom? Sec. B. B23-24.

Miller, M. H. (2010, March 19). Wired campus: How interactive technology can help minority students to learn. The Chronicle of Higher Education. Retrieved from http://chronicle.com/blogs/wiredcampus/how-interactive-technology-can-help-minority-studentslearn/21932

Oblinger, D., \& Oblinger, J. (2005). Educating the net generation. In R. Kvavik, Convenience, communication and control: How students use technology (Chapter 7). Educause Center for Applied Research. Retrieved from Educaus e-book http://net.educause.edu/ir/library/pdf/pub7101.pdf

Oracles Think Quest Education Foundation writers. (n.d.). Color psychology. Retrieved from http://library.thinkquest.org/27066/psychology/nlcolorpsych.html 
Radcliffe, B. (2007). Stuck in the middle: Helping students begin new literacy lives. Voices from the Middle, $15(2), 18$.

Rheingold, H. (2010, June 30). It's the learning. Not the technology. Jessica K. Parker. Digital media and learning: The power of participation. Retrieved from DML Central Web site http://dmlcentral.net/blog/howard-rheingold/its-learning-not-technology-jessica-k-parker

Savannah State University. (2011). Institutional research planning and assessment. Retrieved from Savannah State University Institutional Research Planning and Assessment Web site http://irp.savannahstate.edu/IRP/Common_Data_2010/commondataC.htm

Shanahan T., \& Shanahan, C. (2008). Rethinking content-area literacy. Harvard Educational Review, 78(1), 40-60. Retrieved December 8, 2011, from ProQuest Education Journals.

Smith, A., Raine, L., \& Zickuhr, K. (July 2011). College students and technology. Pew Internet and American Life Project: Main Report. Retrieved from http://pewinternet.org/Reports/2011/College-studentsantechnology/Report/Findings.aspx

Staff writers. (2011). 17 scary stats on minority education in America. Online Colleges. Retrieved from On Line College Site News Web site http://www.onlinecolleges.net/2011/09/19/17-scary-stats-onminority-education-in-america

Venezia, A., Callan, P. M., Finney J. E., Kirst, M. W., \& Usdan, M. D. (2005 September). The governance divide: A report on a four-state study on improving college readiness and success. Retrieved from The Institute for Educational Leadership, The National Center for Public Policy and Higher Education The Stanford Institute for Higher Education Research http://www.highereducation.org/reports/governance_divide/governance divide.pdf

Woodill, G. (2011). The ideal learning management system for multimedia learning. Brandon Hall Group.

\section{Biography}

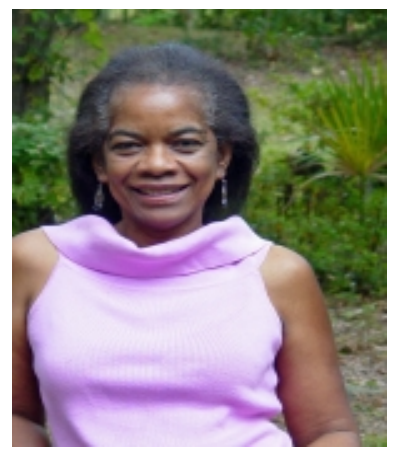

Peggy Blood, Distinguished Professor, Savannah State University, joined the historical black institution, Savannah State University, Savannah, Georgia in 1998. Prior to moving to Georgia, she served as Executive Director for Chapman University's graduate and undergraduate programs in Fairfield and Travis, California.

Professor Blood's research interests borders investigating on-line strategies and intervention for equipping at risk students to achieve better classroom outcomes. Funded by the University system of Georgia; Professor Blood developed Savannah State University's first online course in 1999. Her fifteen years of teaching online courses and merging technology within courses of study has expanded her interest brought forth by the transformation of E-learning interdisciplinary global team teaching. A two year E-learning team project included professors at Shanghai Teacher's University in Shanghai, China; Saint Petersburg State Polytechnical University in Russia, and Kwame Nkrumah University, Ghana, West Africa; followed by three years of team teaching with a professor at Obafemi Awolowo University, IlleIfe, Nigeria.

Presently Professor Blood is participating in a study by American Public University System, Next Generation Learning Challenges to Enhance Student Outcomes through Sakai Learning Management System, Online Academic Analytics Initiative (OAAI) Grant Project lead by Marist College, Poughkeepsie, New York and performamatics Workshop, National Science Foundation (NSF), headed by Boston University.

Dr. Blood holds administrative degrees in MA from Holy Names University, Oakland, California and a PhD from Union Universities in Cincinnati, Ohio. 